\title{
Antigenic response of bovine $\beta$-lactoglobulin influenced by ultra-high pressure treatment in combination with high temperature
}

\author{
Janire Orcajo*, Iñigo Martinez de Marañon, Maria Lavilla \\ From Food Allergy and Anaphylaxis Meeting 2014 \\ Dublin, Ireland. 9-11 October 2014
}

$\beta$-lactoglobulin ( $\beta$-lg), the main whey protein fraction in bovine milk is a major allergen causing cow's milk allergy. Immunological investigations of $\beta$-lg have reported several IgE-binding regions of the protein that were linked with allergic reaction. Most IgE epitopes are specific for surface features of the protein. However, no clear association of structural feature or function with allergenicity has been established.

Heat treatment has been used as a means to influence the functional properties (gelation, emulsification...) of $\beta-\lg$ and it has been proposed as a means to reduce milk protein allergenicity. Although pressure -and temperature-induced denaturation of $\beta$-lg has also been used for modification of the functional properties of the protein, there is a lack of information about the antigenicity as a marker for the allergenic status of $\beta$-lg. Then, the objective of this study is to determine the modification in IgE binding to $\beta$-lg when applying High Pressure (HP), High Temperature (HT) and the combination of both technologies, HPHT.

Samples of $\beta$-lg from bovine milk in several media at different $\mathrm{pH}$ were pressurized at $600 \mathrm{MPa}$ in a range time of 0 to 6 minutes at 25,75 and $95^{\circ} \mathrm{C}$. Concurrently, same samples were treated only by heat treatment at 75 and $95^{\circ} \mathrm{C}$ for same times. Then, an in vitro test by indirect competitive enzyme-linked immunosorbent assay (ELISA) with recombinant monoclonal IgE was performed in order to determine the alterations produced in the specific antigen-antibody immunoreactivity.

The experiments showed little changes in the allergenicity of the $\beta-\lg$ when heat treatments or HP at room temperature were applied. Nevertheless, results of combined HPHT treatments at $600 \mathrm{MPa}$ and temperatures thereupon

Fundacion Azti-Tecnalia Fundazioa, Derio, Spain $75^{\circ} \mathrm{C}$ clearly affect the antigenity of $\beta$-lg. In addition, beyond pressure and holding time temperature is an important parameter to modulate the antigenity of this allergen.

HPHT treatment should be considered as an alternative processing technology for reduction of allergenicity especially in the field of milk and milk products with high allergy risks that can even improve the nutritional and physic-chemical properties.

Published: 30 March 2015

doi:10.1186/2045-7022-5-S3-P49

Cite this article as: Orcajo et al:: Antigenic response of bovine $\beta$-lactoglobulin influenced by ultra-high pressure treatment in combination with high temperature. Clinical and Translational Allergy 2015 5(Suppl 3):P49.

Submit your next manuscript to BioMed Central and take full advantage of:

- Convenient online submission

- Thorough peer review

- No space constraints or color figure charges

- Immediate publication on acceptance

- Inclusion in PubMed, CAS, Scopus and Google Scholar

- Research which is freely available for redistribution 